This item was submitted to Loughborough's Institutional Repository (https://dspace.lboro.ac.uk/) by the author and is made available under the following Creative Commons Licence conditions.

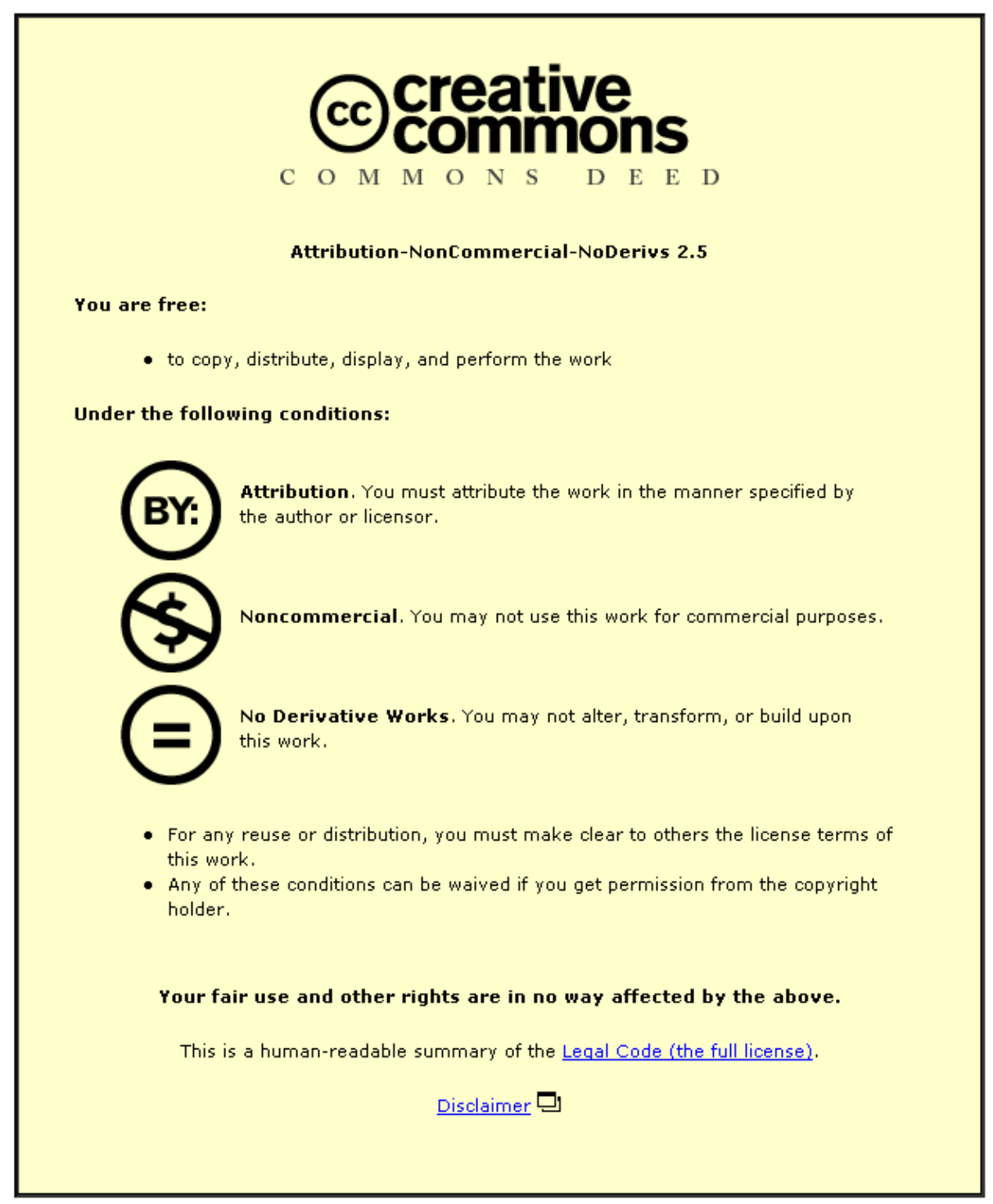

For the full text of this licence, please go to: http://creativecommons.org/licenses/by-nc-nd/2.5/ 


\section{Women in water supply, sanitation and hygiene programmes}

\section{J. Fisher MA, PhD}

This paper demonstrates the fundamental linkages between the United Nations' third millennium development goal (MDG) 'to promote gender equality and to empower women' and MDG 7 'to ensure environmental sustainability', with target 10 'to halve the proportion of people without access to safe drinking water and sanitation by 2015'. A synthesis of the evidence gathered for the Water Supply and Sanitation Collaborative Council (WSSCC) shows the connections between women's wellbeing and water supply, sanitation facilities and hygiene practice. The paper shows that if women's interests relating to water and sanitation provision are at the centre of planning and implementation of programmes, this has a direct impact on women's life experience, their potential and opportunities. This work goes on to provide examples of the benefits to women when they themselves are involved in the planning, implementation and operation of water supply, sanitation and hygiene programmes.

\section{INTRODUCTION}

In September 2000, seven millennium development goals (MDGs) were agreed by the United Nations millennium summit, intended to combat poverty, hunger, illiteracy, environmental degradation and discrimination against women. ${ }^{1}$ The third MDG is 'to promote gender equality and to empower women', measured against the targets of achieving gender parity in education and levels of female literacy and representation in government. MDG 7 is 'to ensure environmental sustainability', with target 10 'to halve the proportion of people without access to safe drinking water and sanitation by $2015^{\prime}$. Indicators for this are the proportions of rural and urban populations with sustainable access to improved water and sanitation.

It appears that success in reaching these targets is still a long way off. Halfway through the period, less than $20 \%$ of developing countries are on track or have achieved the target for safe water access. Less than 35\% have improved access to sanitation, ${ }^{2}$ with the percentage for sub-Saharan Africa actually decreasing. The picture is even bleaker in fragile states, with access to water and sanitation of 6 and 15\% respectively. It is estimated that by the 2015 deadline, the target for improved sanitation access will have been missed for 600 million people. ${ }^{3}$

There is a strong interdependence between the MDGs, how they can be achieved and the benefits they will accrue. A simple example of this is if a woman can get enough safe water for her family from a nearby pump, she has more time and opportunity to improve her life and her family's lives through education, paid work and better health. Furthermore, if women are responsible for decisions about where that pump needs to be placed and what needs to happen to make sure it is well used, the benefits are even greater. Estimates suggest that women and girls in Africa spend a total of 40 billion hours each year fetching and carrying water, that may not even be safe to drink, from sources that are often far away. ${ }^{4}$ In recognition of the fundamental link between MDG 3 and MDG 7, the UN millennium project task force on education and gender equality has proposed that additional indicators for MDG 3 should include the "hours per day (or year) that women and men spend fetching water and collecting fuel'. ${ }^{5}$

This paper provides a synthesis of the evidence gathered for the Water Supply and Sanitation Collaborative Council (WSSCC). ${ }^{6}$ It demonstrates the ways in which women's wellbeing and water supply, sanitation facilities and hygiene practice are inextricably linked. The first section shows that focusing on women's interests relating to water and sanitation provision has a direct impact on the way women experience life, in the tasks they perform, their potential and opportunities and the difficulties they face. The second section takes this further by providing examples of the benefits to women when they are involved in the planning, implementation and operations of water supply, sanitation and hygiene programmes. The work draws on a variety of sources: recent literature, project reports and personal correspondence between the author and those involved in initiatives that are not fully documented.

\section{A FOCUS ON WOMEN'S INTERESTS}

If women's needs, interests and perspectives are placed at the centre of decisions about water supply, sanitation and hygiene promotion programmes and activities, there is evidence of positive effects extending into many aspects of women's lives. These include the opportunity for greater privacy and personal dignity, better all-round health (including during pregnancy and childbirth), increased educational opportunities, better personal safety and more possibilities for earning income.

\section{I. Issues of safety and dignity}

Inadequate water supply and sanitation facilities can seriously compromise the safety and dignity of women and girls. Without sanitation facilities, they may be forced to wait until nightfall to relieve themselves in private, thus making them vulnerable to 


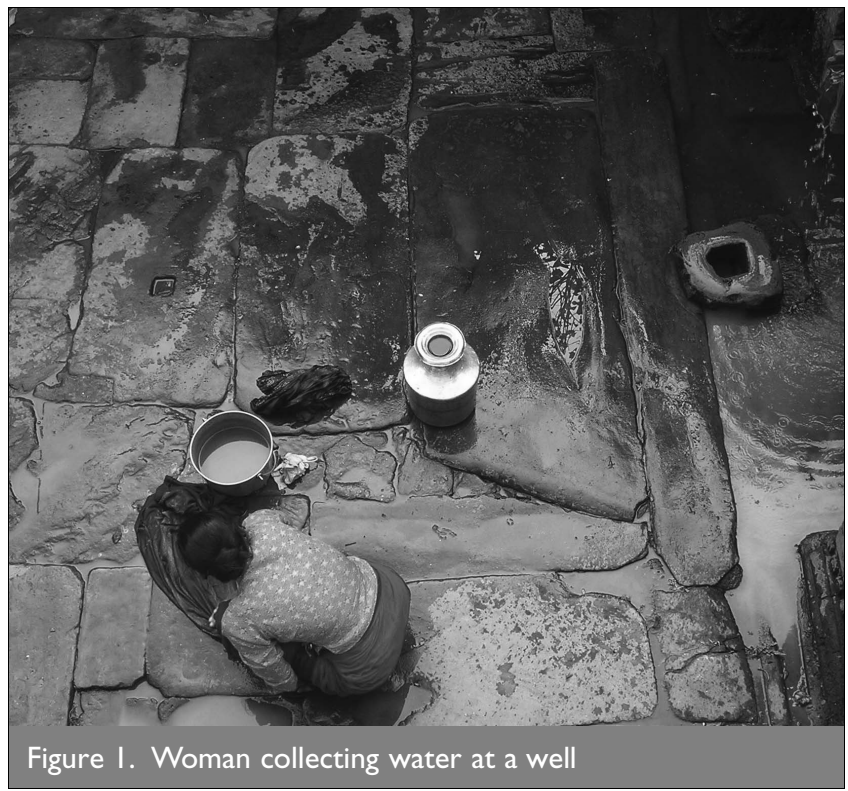

physical or sexual assault in secluded areas. With the provision of appropriate toilets, women and girls can use them at any time, in private, without shame, embarrassment or fear. ${ }^{7}$ This is a liberating development for women whose lives can often be dominated by this basic need.

Accessing some sources of water can also present dangers (Figure 1). In Kenya, Nakwetikya, a 60-year old Masai woman, has benefited from a new water source as she no longer has to climb down the very dangerous open wells that were the previous means to access water. ${ }^{8}$ Nakwetikya's sister was crushed to death when a well collapsed, leaving her to bring up her sister's four children. Before the improvements, cholera was an annual occurrence. The incidence of diarrhoea was high, with frequent child deaths including three of Nakwetikya's children.

Where facilities are provided, they may not necessarily be designed to meet the physical and psychological demands of women. The South African aqua privy ${ }^{9}$ requires water to be poured into the toilet bowl after use and the sludge emptied periodically by women (a task that can render her unmarriageable). Other problems include the fact that fetching water is an obvious sign that a woman needs to use a toilet, toilets often face the street (causing embarrassment and harassment), sanitary pads cannot be flushed into the bowl and the toilets are too small for pregnant women and women with children to use comfortably.

In contrast, Utthan ${ }^{10}$ (an Indian implementing support agency) aims to improve water and sanitation services through capacity building and community mobilisation. Half of all local committee members are women and women-focused hygiene programmes have been established. Utthan shows women advocating for the sanitation systems and stand posts that they really want, that is, those that offer them privacy and safety. Furthermore, loan schemes have been set up to enable households to buy them.

Associated with this, women's dignity is often compromised by the symptoms of menstruation, pregnancy and the post-natal period. When the women in Songambele village, Tanzania, were able to bathe regularly during menstruation, they reported that their improved personal hygiene resulted in increased confidence. Prior to this, women who were perceived to have

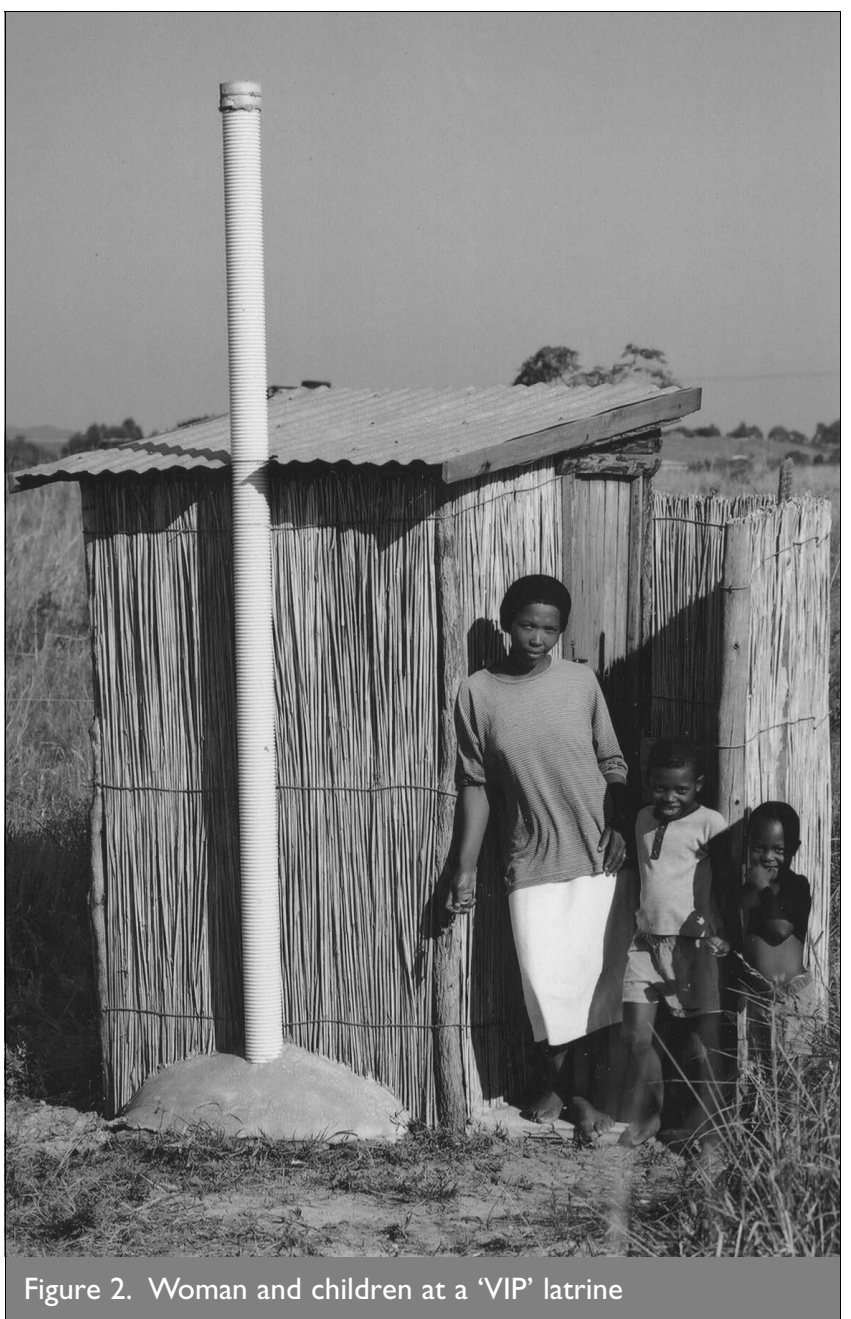

problems maintaining levels of cleanliness suffered intense humiliation by being taken before the elders. ${ }^{11}$

Ensuring women's safety and privacy leads to their greater selfconfidence (Figure 2). An assessment of the impact of water, sanitation and hygiene interventions ${ }^{12}$ describes the experience of Mdala Herieti of Berege, Tanzania, who confirms that having water near women's homes has improved menstrual hygiene and made women feel more confident in front of others.

\subsection{Health and wellbeing}

Water, sanitation and hygiene interventions result in widespread health improvements for the whole community, primarily by lowering the incidence of water-borne and communicable diseases. ${ }^{13}$ This is advantageous for women, not only for their own health, but also as they have the main responsibility of caring for the sick.

Evidence suggests that years spent carrying heavy loads of water over long distances can injure the back and neck (Figure 3). The 'back happy' tapstand in rural Tibet has a waist-high shelf and a higher tap, thus allowing women to fill 15-20 litre metal jars of water without bending. Women report that this design has improved their quality of life. ${ }^{14}$

The other major specific health impact on women is caused by having to delay relieving themselves. ${ }^{15,16}$ This increases the likelihood of urinary tract infection and chronic constipation, as well as causing psychological stress. Furthermore, in rural 


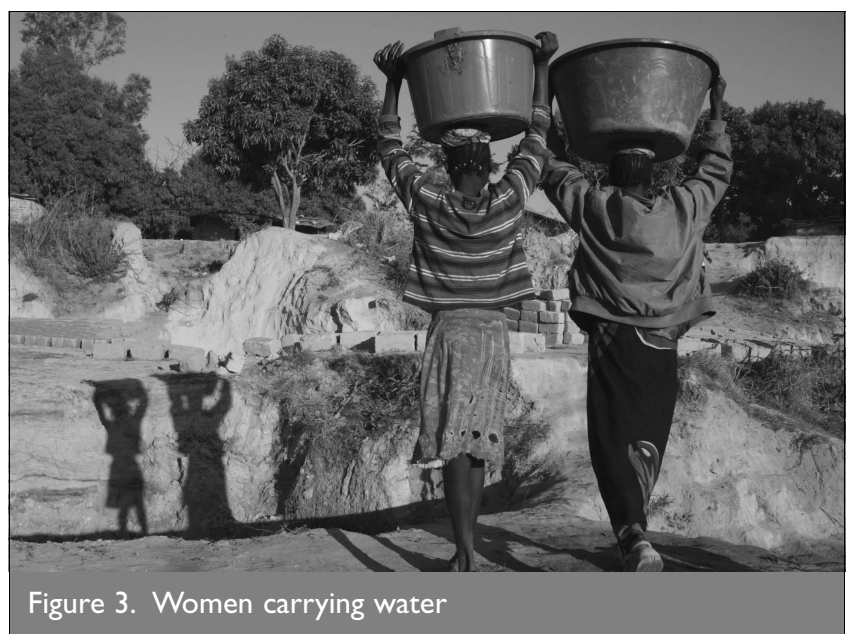

Bangladesh, urinary and vaginal infections are common amongst women whose only form of sanitary protection is 'nekra' rags, torn from old saris and washed in unclean water. ${ }^{17}$

2.2.1. Pregnancy and childbirth. 'Improving maternal health' is MDG 5; its target is to reduce the number of women dying in childbirth by $75 \%$ by 2015 . Many of the determinants of maternal and infant health and wellbeing are multi-sectoral and require programmes that provide improvements beyond the health sector. Gender inequalities, including poor access to and control of resources, are linked strongly to maternal morbidity and mortality in sub-Saharan Africa. ${ }^{18}$

Easy access to safe water improves maternal health, partly as pregnant women no longer have to struggle with heavy loads of water several times a day. ${ }^{19}$ It is known that carrying traditional water pitchers on the hips can cause difficulties during pregnancy. ${ }^{20}$ Sickness through water-borne disease is also avoided through the use of clean water and better hygiene. Pregnant women face a greater risk of hookworm infestations, which has been linked to low birthweight and inhibited child growth. Studies in Haiti show that good hygiene and access to plentiful clean water reduce these risks. ${ }^{19}$ Water of good quality for pregnant women is also vitally important to protect them from serious diseases such as hepatitis. ${ }^{21}$

Puerperal infections are mainly caused by unhygienic practices and poor infection control in labour and delivery ${ }^{22}$ and are the cause of $15 \%$ of all maternal deaths. ${ }^{23}$ The promotion of hand-washing and hygienic practices during childbirth reduces the chances of such infection. In Tanzania, increased availability of water during and after childbirth reduced postnatal infections. Blagborough ${ }^{12}$ reports that the work of traditional birth attendants such as Mdala Rhoda in Songambele village, Tanzania, was made easier and more effective by being able to replenish her supply of water.

2.2.2. Disability. Disabled women and men benefit directly from innovations that make their use of water and sanitation easier by being able to wash and attend to their needs without help, being less restricted and being able to contribute to the family's livelihood. Jones and Reed ${ }^{24}$ provide evidence of specific impacts on disabled women. Mrs Rong Ry, paralysed below the waist, is a wheelchair user living with her husband and children in a rural village in Siem Province, Cambodia. The family has constructed a screened bathing area made from palm leaves and plastic sheet on a bamboo frame, big enough for a wheelchair to turn in, with a bathing bench and a water storage jar. This allows her to transfer from her wheelchair to the bench for personal washing and doing laundry. Previously, she remained upstairs and was dependent on her husband for personal care.

A further example is Mrs Pethayee from Ponnusangampatti, Tamil Nadu, India, who struggles to walk due to polio. Water Partners International installed a western-style toilet rather than a traditional squat-style latrine, which is easier for her to use. ${ }^{25}$

Caring for disabled individuals within the household often falls naturally on women. Any measures that can assist the disabled person in their use of water and sanitation facilities also make the job of the carer easier. Jones and Reed ${ }^{24}$ provide a further example. Nine-year old Shathi lives with her family in one room in a slum area of Dhaka, Bangladesh. Shathi, who has cerebral palsy, has a metal commode chair on which she is able to sit without support. For her mother, the toilet chair means she spends less effort providing basic care for her daughter, freeing up time to take her to the therapy centre and to grow vegetables for the family to sell for extra income.

\subsection{Education}

Water and sanitation related diseases can affect children's physical and mental development and sickness prevents them attending school. Of the 120 million school-age non-attenders worldwide, the majority are girls. Regionally, this means that $41 \%$ of all primary-school-aged girls who are not enrolled at school live in South Asia and 35\% live in sub-Saharan Africa. The effect of this lack of schooling is that two-thirds of all those who are illiterate in the world are women. ${ }^{26}$

Table 1 shows the level of inequality between the proportions of boys and girls who go to school. ${ }^{27}$ This can be partly attributed to the lack of convenient clean water supply and safe sanitation at community level. Girls, just like their mothers, have prime responsibility for providing the family with enough water to meet their daily needs for drinking, washing and cooking. The equation is simple: when women and girls have easy access to a clean water supply, less school time is lost fetching water. ${ }^{28}$

There is strong evidence to confirm this link. School attendance by girls has risen since the introduction of water points in four communities in Arappalipatti and Panjapatti, India, which has, in turn, increased women's literacy levels. ${ }^{12}$ The rural water supply and sanitation project of the World Bank in Morocco found a $20 \%$ increase in school attendance over four years, attributed in part to a reduction of between 50-90\% in the time required for fetching water. ${ }^{29}$

\begin{tabular}{|lcc|}
\hline & $\begin{array}{l}\text { Ratio of female to male } \\
\text { enrolments in primary and } \\
\text { secondary school: \% }\end{array}$ \\
\cline { 2 - 3 } & 1990 & 2000 \\
\hline East Asia and Pacific & 83 & 97 \\
Middle East/N. Africa & 79 & 95 \\
South Asia & 68 & 79 \\
Sub-Saharan Africa & 79 & 82 \\
\hline Table I. School attendance by gender and region & 27 \\
\hline
\end{tabular}


Furthermore, female pupils, especially those who are pubescent and menstruating, can be deterred from attending school if there are no private and separate sanitation facilities and a clean water supply. ${ }^{30}$ An assessment of 20 schools in rural Tajikistan revealed that all girls chose not to attend during their menstruation as there were no sanitation facilities available. ${ }^{31}$ Where these are provided, school enrolment increases and drop-out rates decrease. ${ }^{30}$

Predictably, the recruitment and retention of female teachers is also affected by a lack of services, both at school and at home. WaterAid reports that, since their clean water programmes in India, Tanzania and Ghana, teachers are more likely to accept posts in these areas which formerly were difficult to fill. ${ }^{12}$

\subsection{Income generation}

Where there is no convenient water source, a great deal of time can be spent walking long distances-African and Asian women walk an average of $6 \mathrm{~km}$ each trip in order to fetch water. ${ }^{12} \mathrm{~A}$ Unicef study of rural households in 23 sub-Saharan countries found that a quarter of women spent 30 minutes to an hour each day collecting and carrying water, and 19\% spent an hour or more. ${ }^{32}$ In Mile Gully, Jamaica, women spend on average between two to five hours carrying water every day.

Additionally, time is spent going to the river to wash and, on average, washing takes place three times a week. ${ }^{33}$ This clearly has implications for women's ability to undertake other activities.

Providing local water sources frees up time for women and leads to both direct and indirect opportunities to engage in activities that provide income. ${ }^{34}$ Direct opportunities are those that allow women to develop particular aspects of income generation that need a supply of water. Indirect opportunities are those that become open to women as more time becomes available as a result of a convenient water supply.

2.4.1. Making an income from water. There are many examples where women have become involved in the provision of water. This can mean setting up their own licensed water vending points. The results have been a fairer, fixed price for water and employment for the women servicing the water points, with the profits contributing to funding local community projects. Since state subsidies have been used in Bangladesh to install deep wells with mechanised pumps, women have become water vendors, thereby directly benefiting financially from the new technology. ${ }^{35}$

Women are also able to earn a living by providing support for improved services. In Nyakitunda, Uganda, a Unicef programme promoting rainwater harvesting trains women in all associated technical, marketing and management aspects of water provision. With seed funding for premises and casting yards, the women make and sell water jars and slabs. Bwengye-Kahororo ${ }^{36}$ states that the scheme has given women more time for housework and farming and that their daughters are more likely to attend school.

A good water source can provide additional income-generating opportunities for women in activities that require plentiful, clean water, e.g. brewing, running teashops and laundering clothes. ${ }^{37}$ There is a significant amount of evidence in support of this. For example, the Self-Employed Women's Association (Sewa) comprising 215000 poor self-employed women, launched a tenyear water campaign in nine districts of Gujarat, India.
Watershed committees were established, with at least seven of the eleven members being women including a female chair. As a result, 15 farm ponds were constructed, 120 tube wells recharged, 20 village ponds repaired, 3 check dams recharged and 15 open wells established. Women in the community have been able to benefit from the more productive land through a range of green belt employment opportunities. ${ }^{37}$

In another example, in Bangladesh the Grameen Bank and Grameen Krishi Foundation deep-tube well programme was aimed at linking agricultural efficiency with women's empowerment. As agricultural work provides local women with more income than their traditional areas of work, improved irrigation schemes led to increased income, giving women more confidence and reducing their dependence on men (Figure 4). ${ }^{38}$

Clearly, there are benefits for women emanating from involvement in water-related activities, either in support of its supply or using it as a resource. These offer associated benefits such as increased status, financial security and confidence.

\subsubsection{Releasing time to earn an income. It has been}

demonstrated that convenient water and sanitation services lead to significant time savings, which in turn impact on women's income earning capacity. WaterAid ${ }^{39}$ recounts the experience of a mother of six, Mrs Gamma, who is a founder member of the WaterAidfunded Lifuwu Water Project Committee in Malawi. The former unprotected well has been replaced by a handpump and is maintained by the community. Women report that as a consequence of the supply of safe water, less time is now spent caring for sick children, they have more time to work the land and have built a new school. Mrs Gamma has plans to use the manure from the pit latrines to improve her crops and sell them. In India, Gujarati, women's economic productivity has also increased due to time savings. An additional programme of support for the women to develop handicrafts addressed the usual constraints to taking up new enterprises-lack of funds and poor access to credit. ${ }^{40}$

Clearly, time saved in water carrying does not generally result in women being less productive. ${ }^{12}$ Only the nature of the tasks change. However, there is evidence to suggest that quality of life may still be improved. Hoogervorst ${ }^{41}$ demonstrates the impact of a Netherlands Development Organisation (SNV) programme in Benin, which constructs boreholes to provide safe drinking water. An evaluation noted that while women enjoyed time savings, they then increased

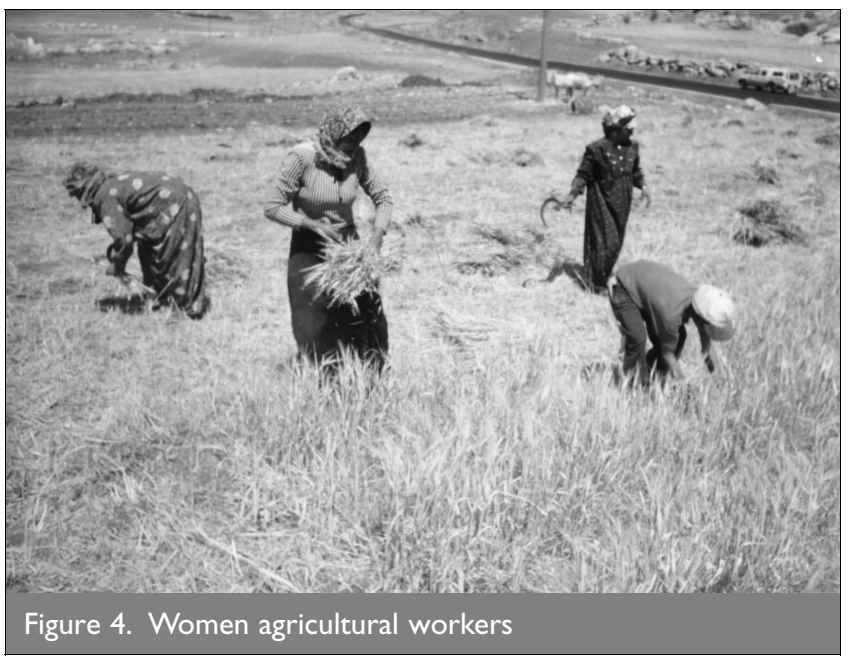


the time spent working on the fields with their husbands. Despite this heavy workload, women felt that life was easier overall.

\section{A CENTRAL ROLE FOR WOMEN}

Women who become involved in the planning, design and implementation of water, sanitation and hygiene interventions often find this an empowering experience (Figure 5). Both the women concerned and the wider female community are now seen as having skills and potential. This general improvement in status within the home and community opens up many kinds of opportunities for women, including different means of income generation and, sometimes, the possibility of going on to occupy other public and influential roles.

\section{I. Improved status}

A poignant demonstration of the change in women's status due to their involvement in a community water committee is given by the words of Nakwetikya of Ndedo village in Tanzania ${ }^{42}$

Three years ago, before we formed a committee and prepared ourselves as a community for the water source, men just saw women as animals. I think they thought of us as bats flapping around them. They had no respect and no one would allow you to speak or listen to what you had to say. When I stand up now in a group meeting I am not an animal. I am a woman with a valid opinion. We have been encouraged and trained and the whole community has learnt to understand us. I was treated like a donkey only fit to carry baggage all the time. Or a scrap of paper, just rubbish in the wind. I can assure you though, that if you come back in a few years you will see that women will be leaders of this village. That will bring so many benefits to everyone!

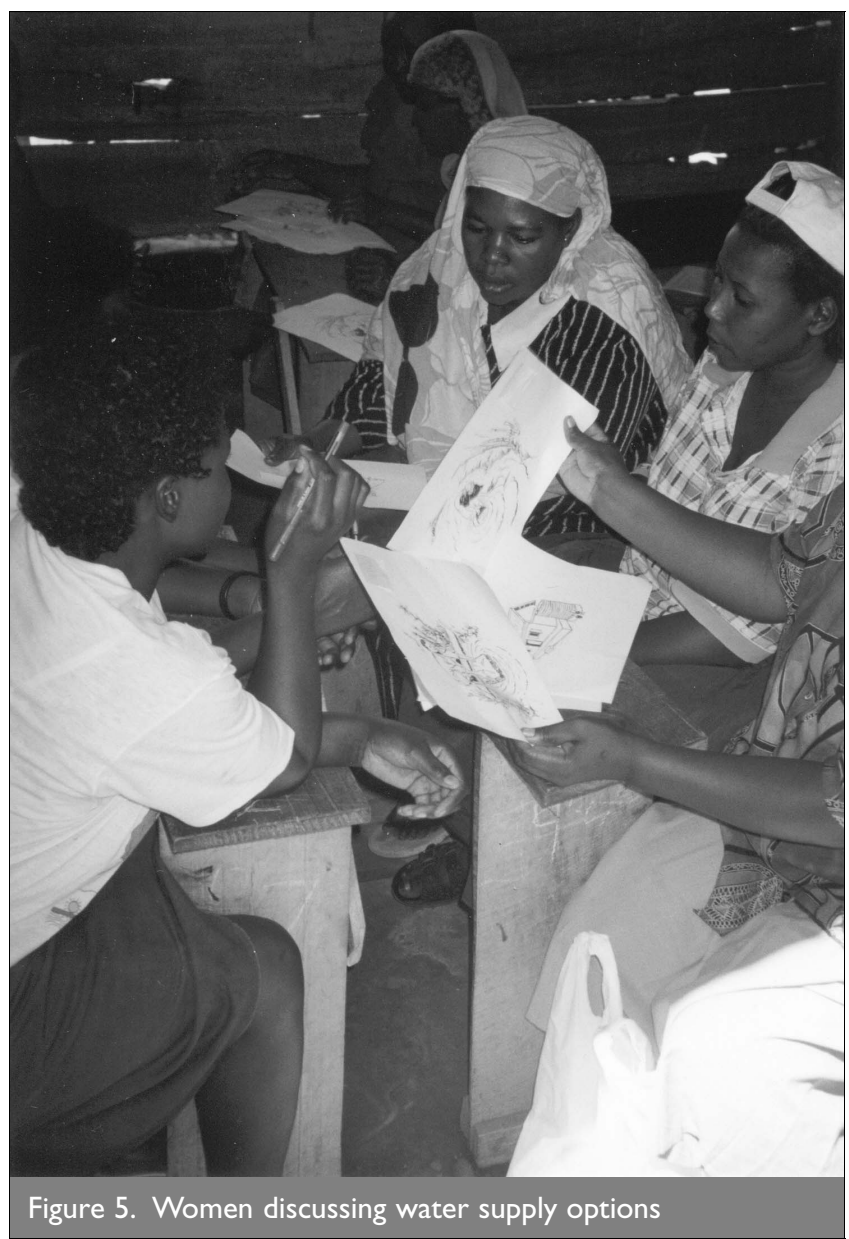

These changes, however, may not be without opposition.

In Hoto village, Pakistan, women were allowed to assist in the strategic development of a drinking water supply. Women's suggestions were adopted as the most cost-effective measures despite the fact that they were contrary to those of the men. As a consequence, the position of the women became one of active participation in the community. They have since demanded hygiene education for women, and have organised household contributions towards operation and maintenance of the water system. The most significant effect is judged to be that they are now sending their daughters to school. ${ }^{43}$

A further impact of women's involvement has been shown to be an increase in their areas of responsibility and influence. This is demonstrated by the work of Acord-a Tanzanian women's organisation working with local government in the Geita township-to identify water sources and carry out participatory analysis of water use patterns in the community. Forty percent of newly established water source committees are made up of women and this has acted as a springboard for them to engage with local development issues relating to education and the environment. ${ }^{44}$

\subsection{Women as positive role models}

Women actively involved in water resources management can provide a positive role model for other women in the community. For example, Shanti Bhut is a 21-year old married woman in Baitandi, Nepal. Formerly vice chair of a gender and casterepresentative Water and Sanitation User Committee and trained as a paid maintenance caretaker, she has progressed to become vice president of a gender-sensitive savings and credit steering committee. Her skills and ability to earn an independent income mean that she is a source of pride to her in-laws and she is held up to other women as a positive role model within the community. ${ }^{45}$

Similarly, on the island of Hispaniola, in the Dominican Republic, the influential role of women in water supply projects has led some individuals into local politics or study, while others have gained the confidence required simply to negotiate their own needs. ${ }^{46}$

\subsection{Women as skilled workers}

There are many examples of women involved directly in the technical operations and management of water and sanitation services. This requires a certain level of training and expertise, and challenges traditional perceptions about women's status, skills and capabilities held by the community, the family and even the women themselves. Coordinated by Care-El Salvador, the Agua project has promoted leadership in women, encouraging them to participate on the boards of directors of various water systems and training them as community producers, promoters and managers of small companies.

There are many other instances in which women successfully carry out technical jobs, for example, as latrine builders (Figure 6) or handpump caretakers. ${ }^{12,47,48}$ Although women in India were not initially well received as mechanics for the India Mark II handpump, they have earned the reputation of being effective, skilful and dependable. ${ }^{49}$

Such employment can provide an opportunity for selfsufficiency when women have no male relative to support them 


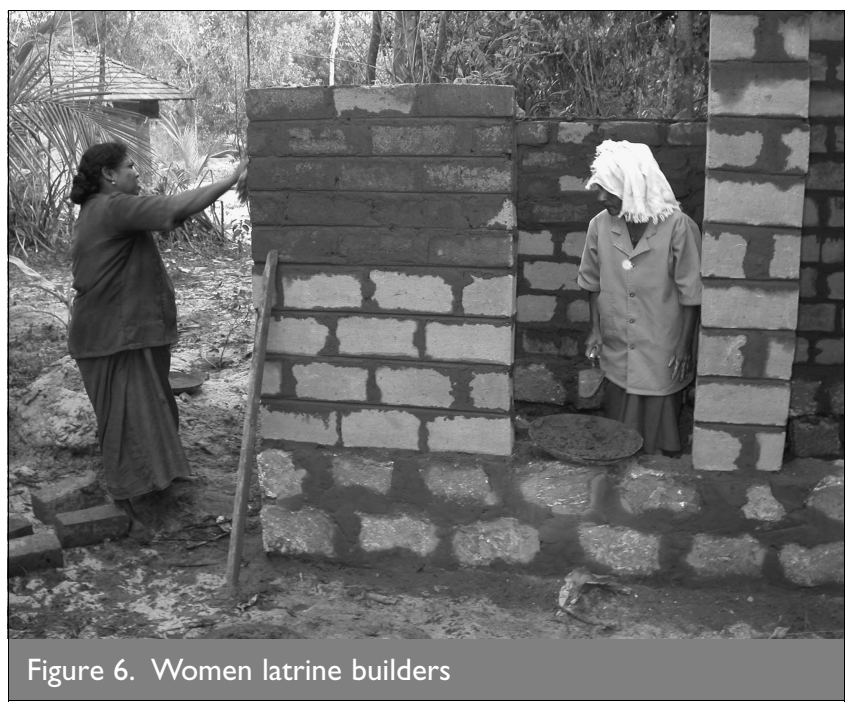

and their children. Nepal Water for Health ${ }^{50}$ describe the case of a 34-year old Nepalese woman who was trained as a mason on a drinking water, hygiene education and sanitation project.

Abandoned by her husband, she is the sole breadwinner for her two children and now works building latrine superstructures and foundations, installing pans and constructing slabs and rings. In spite of opposition from male masons reluctant to work alongside a woman, she is now a successful skilled mason and is able to provide for her children independently.

\section{CONCLUSIONS}

There is a great deal of evidence of the positive effects arising from positioning women and their interests at the heart of planning and implementation of improvements to water supply and sanitation. The examples in this paper come from a wide range of sources and locations around the world, but the fundamental impact is always the same: the intervention is more successful and sustainable, resulting in many and varied improvements to the quality of life of the women affected and the community in general. The success rate of these interventions is seen to be largely due to the fact that women have a good knowledge of local water and sanitation practices which, when incorporated into intervention programmes, result in improved health and quality of life for them and the community. It is important that these effects are recognised by the engineering sector, with the consequence that they inform the planning, design and construction of future water supply and sanitation services.

The impacts on the lives of individual women are many and varied, but include more active roles for women in aspects of community decision-making including

(a) opportunities to make a valuable contribution to their families' livelihoods or to gain financial independence

(b) an increase in female school attendance and a decrease in drop-out rates

(c) reductions in child mortality and maternal morbidity and mortality

(d) improved health for women and girls

(e) increased privacy and dignity

$(f)$ less physical injury from carrying heavy loads of water.

Returning to a consideration of the MDGs, this evidence of firm linkages between MDG 3 and MDG 7 provides an invaluable advocacy tool for the implementation of more people-centred and gender-sensitive approaches.

\section{ACKNOWLEDGEMENTS}

This paper is based on the WSSCC For Her it's the Big Issue, ${ }^{6}$ written by the author for 2006 sanitation and hygiene week. The author wishes to acknowledge the assistance and contribution of the WSSCC, the Ministry of Foreign Affairs Norway, Unicef and the Gender and Water Alliance in the production of the original report.

\section{REFERENCES}

1. See http://www.un.org/millenniumgoals/ for further details. Accessed 25/01/2008.

2. World Bank. Global Monitoring Report 2007: Millennium Development Goals: Confronting the Challenges of Gender Equality and Fragile States. World Bank, Washington, DC, 2007.

3. United Nations. The Millennium Development Goals Report 2007. United Nations, New York, 2007.

4. Cosgrove W. and Rissberman F. Creating a vision for water, life and the environment. Water Policy, 1998, 1, No. 1, 115-122.

5. United Nations Development Programme. Looking for Equality: A Gender Review of National MDG Reports. UNDP, New York, 2005.

6. Water Supply and Sanitation Collaborative Council. For Her it's the Big Issue: Putting Women at the Centre of Water Supply, Sanitation and Hygiene. WSSCC, Geneva, 2006. See http://www.genderandwater.org/page/5124 for further details. Accessed 25/01/2008.

7. Water Supply and Sanitation Collaborative Council. Resource Pack on the Water and Sanitation Millennium Development Goals. WSSCC, Geneva, 2004. See http://www.wsscc.org/home.cfm?CFID = 1056840\&CFTOK $\mathrm{EN}=62467993$ for further details. Accessed 25/01/2008.

8. WATERAID. Ndedo village, Tanzania. Personal communication $16 / 11 / 2005$.

9. Muoli-Mncube N. The impact of an alternative sanitation system on the lives of women in South Africa. Science, Technology and Development, 1997, 15, No. 2-3, 104-111.

10. Utтhan. Personal communication 10/11/2005.

11. Thompson J. (ed.) Drawers of Water II. IIED, London, 2001.

12. Blagborough V. (ed.) Looking Back: The Long-term Impacts of Water and Sanitation Projects. WaterAid, London, 2001.

13. Department for International Development. Guidance Manual on Water Supply and Sanitation Programmes. DFID, London, 1998.

14. Hoy D., Toole M. J., Morgan D. and Morgan C. Low back pain in rural Tibet. The Lancet, 2003, 361, No. 9353, 225-226.

15. Gender ANd WATER. Egypt: Empowering Women's Participation in Community and Household Decision-making in Water and Sanitation. See http://www.genderandwater.org/page/5685 for further details. Accessed 25/01/2008.

16. UnICEF. Meeting the MDG Drinking Water and Sanitation Target, A Mid-term Assessment of Progress. 2005. See http://www.unicef.org/wes/mdgreport/disparities2.php for further details. Accessed 25/01/2008.

17. Ahmed R. Achieving 100\% Sanitation: WaterAid Bangladesh and VERC approach. WaterAid, Bangladesh, 2006. See http://www.wateraid.org/documents/ plugin_documents/achieving_100_sanitation.pdf for further details. Accessed 25/01/2008. 
18. Simwaka B., Theobald S., Peprah Amekudzi Y. and Tolhurst R. Meeting Millennium Development Goals 3 and 5. British Medical Journal, 2005, 331, No. 7519, 708-709.

19. Beach M. J., Streit T. G., Addiss D. G., Prospere R., Roberts J. M. and LAmmie P. J. Assessment of combined Ivermectin and Albendazole for treatment of intestinal helminth and Wucheraria bancrofti infections in Haitian schoolchildren. American Journal of Tropical Medicine and Hygiene, 1999, 60, 479-486.

20. Sultana F. and Crow B. Water concerns in rural Bangladesh: a gendered perspective. In Proceedings of the 26th WEDC Conference-Water, Sanitation and Hygiene: Challenges of the Millennium, Dhaka, Bangladesh, 2000, 416-419.

21. World Health Organization/Unicef. Water for Life: Making it Happen. WHO/UNICEF, Geneva, 2005.

22. Gelband H., Liljestrand J., Nemer L., Islam M. and Zupan J. The Evidence Base for Interventions to Reduce Maternal and Neonatal Mortality in Low- and Middle-income Countries. WHO, Geneva, 2001, Commission of Macroeconomics and Health Working Paper No. 5. See http://www.popline.org/ docs/170288 for further details. Accessed 28/01/2008.

23. Goodburn E. and CAmpbell O. Reducing maternal mortality in the developing world: sector-wide approaches may be the key. British Medical Journal, 2001, 322, No. 7291, 917-920.

24. Jones H. and ReEd B. Water and Sanitation for Disabled People and Other Vulnerable Groups: Designing Services to Improve Accessibility. WEDC, Loughborough, 2005.

25. Water Partners International. Post Card from the Field: Jan 27 2005-Ponnusangampatti, Tamil Nadu, India. WPI, 2005.

26. United Nations Development Programme. The Global Challenge: Goals and Targets. UNDP, New York, 2004. See http://www. undp.org/mdg/ for further details. Accessed 28/01/2008.

27. WorLd BANk. World Bank Development Report: Making Services Work for Poor People. Oxford University Press, Oxford, 2004.

28. Water Supply and Sanitation Collaborative Council. Resource Pack on the Water and Sanitation Millennium Development Goals. WSSCC, Geneva, 2004. See http://www.wsscc.org/ home.cfm?CFID = 1056840\&CFTOKEN $=62467993$ for further details. Accessed 28/01/2008.

29. WORLD BANK. Implementation Completion report on a Loan in the Amount of US\$10 Million Equivalent to the Kingdom of Morocco for a Rural Water Supply and Sanitation Project. World Bank, Washington, DC, 2003, Report No. 25917.

30. VAN WIJK C. A. Scaling up community-managed water and sanitation in India. In The Sector Reformed: Institutional Challenges in the Water and Sanitation Sector in India (VAN WiJK C. A. and VAN DiJK M. P. (eds)), Manohar, New Delhi, 2004.

31. Mooljman A. Assessment of 1994-2001 UNICEF School Sanitation and Hygiene Project in Khatlon, Tajikistan. UNICEF CARK, Almaty, 2002.

32. UNICEF. Report on the Interagency Task Force on Water and Gender. 2005. See http://www.un.org/esa/sustdev/ inter_agency/gender_water/gender_water_rep_23_02_05. pdf for further details. Accessed 28/01/2008.
33. Gender Water and Sanitation Project. Sponsored by the Ministry of Water and Housing and Canada Caribbean Gender Equality Programme, 2005. See www.csdwand.net/data/ sheet.aspn?cn = Jamaica\&tfn = LA1049 (accessed 31/10/2008).

34. Moriarty P. and Butterworth J. The Productive Use of Domestic Water Supplies. IRC, Delft, 2003, Thematic Overview Paper.

35. Van Koppen B. Gender and Water Rights, Burkina Faso and Bangladesh. Department of Irrigation and Soil Conservation, Wageningen, 1997. See www.undp.org/water/genderguide/ 4_6_rights.html for further details. Accessed 28/01/2008.

36. Bwengye-KaHororo E. Coping Strategy in Water-stressed Areas: A Case Study of RWH in Nyakitunda Sub-county, Mbarara district. Personal correspondence 15/11/2005.

37. World WATER Council. Mainstreaming Gender in Water Resources Management: Why and How. WWC, Paris, 1999.

38. JoRDANS E. and ZWARLVEEN M. Gender and poverty alleviation, Bangladesh. In A Well of One's Own, Gender Analysis of an Irrigation Program in Bangladesh. International Irrigation Management Institute and Grameen Krishi Foundations, Bangladesh, 1997. See www.undp.org/water/genderguide/ 4_5_poverty.html for further details. Accessed 28/01/2008.

39. WATERAid. Lifuwu Water Project Committee. Personal communication 16/11/05.

40. James A. J., Verhagen J., Van Wijk C., Nanavaty R., Parikh M. and BнAтт M. Transforming time into money using water: a participatory study of economics and gender in rural India. Natural Resource Forum, 2002, 26, No. 3, 205-217.

41. HoOgeRVORST J. Benin: Borehole has Unforeseen Effects for Women. 2005. See www.irc.nl/page/7810 for further details. Accessed 28/01/2008.

42. WATERAid. Out from the depths. Oasis: The WaterAid Journal, 2003, Spring/Summer, pp. 6-7.

43. Gender and Water Alliance. Advocacy Manual for Gender and Water Ambassadors. GWA, Dieren, 2003.

44. Acord. Women: Water, Sanitation and Hygiene in Geita District, North Western Tanzania. Personal correspondence 14/11/2005.

45. Newah. Case Study of Empowerment. Personal communication 14/11/2005.

46. Williams A. Incorporating a gender perspective in rural water and sanitation projects. Water in the Americas in the 21 st Century Forum, Mexico City, 2002, pp. 1-8.

47. WoRLd Water VISION. Mainstreaming Gender in Water Resources Management. World Water Vision Unit, Marseille, 1999.

48. Visschel J. T. and VAn De WeRTT K. Towards Sustainable Water Supply: Eight Years of Experiences from Guinea-Bissau. International Water and Sanitation Centre, The Hague, 1995. See www.undp.org/water/genderguide/4_4_technical.html for further details. Accessed on 28/01/2008.

49. UnICEF. Real Lives, 2004. See http://www.unicef.org/ infobycountry/nigeria_1468.html for further details. Accessed on 28/01/2008.

50. NePal Water for Health. Determined to be Self Employed After Separating with her Husband. Personal communication $14 / 11 / 2005$.

\section{What do you think?}

To comment on this paper, please email up to 500 words to the editor at journals@ice.org.uk

Proceedings journals rely entirely on contributions sent in by civil engineers and related professionals, academics and students. Papers should be 2000-5000 words long, with adequate illustrations and references. Please visit www.thomastelford.com/journals for author guidelines and further details. 